\title{
Petrographic studies to delineate suitable coal seams for coal liquefaction and their palaeo-environmental analysis: A case study from the Ib river and Mand-Raigarh coalfields of the Mahanadi valley coalfields, India
}

\author{
Geethumol Kanavarackal Gangadharan*, Chhatrapal Prahladrao Ramteke \\ and Shankar Nath Chaudhuri \\ Specialised Coal Petrography Laboratory, Geological Survey of India, NEnR, Kolkata 700 091, India. \\ *Corresponding author. e-mail: geethukg@gmail.com
}

MS received 3 September 2018; revised 11 February 2019; accepted 26 February 2019; published online 17 June 2019

A systematic approach has been carried out to delineate the coal seam zones from the Ib river coalfield, Odisha and the Mand-Raigarh coalfield, Chhattisgarh for the conversion of coal to oil as well as to establish the peat-forming environment of the mire and determine the depositional facies analysis of the coal seams. Zone R-I of Raniganj formation and Belpahar, Parkhani and Lajkura of Barakar formation from the Ib river coalfield and Seam nos. VII, VI, III and I of the Barakar formation from the MandRaigarh coalfield are identified based on their high percentage of liptinite and reactive content as well as their suitable maturity (mostly sub-bituminous rank) as potential for coal-to-oil conversion. The palaeo-depositional environment for peat formation has been constructed using the tissue preservation index and gelification index following coal facies analysis which shows that the peat formation in the Ib river coalfield took place under limnic to limno-telmatic conditions with prolonged wetness in the mire, whereas in the Mand-Raigarh coalfield, peat evolved under a clastic to an open marsh limnic environment with intermittent wet and dry spells. The microlithotype composition indicates that both the coalfields evolved under lower to upper deltaic settings.

Keywords. Coal liquefaction; Ib river coalfield; Mand-Raigarh coalfield; Mahanadi valley.

\section{Introduction}

The organic carbon content in petroleum source rock may be less than $1 \%$. Coals, on the other hand, contain high content of organic matter and may act as source rocks for not only gas but also for oil as well (Thomas 1982; Durand and Parratte 1983; Littke et al. 1990; Levine 1993). As Type II kerogen in oil, the bituminite in coal is commonly very important for its high oil-rich characteristics (Tissott and Welte 1984). During bituminisation, petroleum substances are generated from liptinites and perhydrous vitrinites, and this is the main reason that low rank coals $(0.4-1.3 \%$ Ro) are suitable for hydrogenation. Coal as a source rock for oil has become a modern concept since Brooks and Smith (1967) first detected petroleum-like substances in Australian coals. Since then, pyrolysis studies, mainly RockEval pyrolysis, revealed that coals have a potential for petroleum formation (Durand and Oudin 1979; Durand and Parratte 1983; Teichmuller and Durand 1983; Singh 2013, 2016a; Singh et al. 2016b, 2017a, b). 
Compositional make-up and rank of a coal has got tremendous significance in determining the quality of coal and suitability for specific applications (Teichmuller and Durand 1983; Singh 2012). Coal liquefaction is the procedure adapted in the Indian scenario in the recent past to produce synthetic fuel as a substitute for crude oil. Low rank coals having high hydrogen content (liptinite content $>15 \%$ ) with the desired $\mathrm{H} / \mathrm{C}$ ratio $>0.9$ (Fleet and Scott 1994) and higher proportions of reactive components $(>75 \%)$ such as vitrinite and liptinite are considered to be suitable for the conversion of coal to liquid.

\section{Geological setup of the area}

The Mahanadi master basin is a riftogenic Gondwana basin which follows a regional NW-SE trend and is considered as a major coal-bearing sedimentary basin of India. The master basin mainly comprises Korba, Hasdo-Arand and Mand-Raigarh coalfields of Chhattisgarh and the south-eastern part of the basin is known as the Ib river coalfield and Talchir coalfield of Odisha (figure 1).
In the Ib river coalfield, the Gondwana sediments to the north and the central part of the coalfield are flanked by older metamorphics of the Gangpur group while in the southern part (bounded by the southern fault boundary), the Gondwana strata rest unconformably over the metamorphic basement of the Chhattisgarh group (Chaudhuri 1983). Two to four coal seam zones (from R-IV to R-I in descending order) occur in the Raniganj formation in different parts of the basins and the Barakar formation hosts five regional coal seam zones (namely, Belpahar, Parkhani, Lajkura, Rampur and Ib from top to bottom).

In the Mand-Raigarh coalfield, a thick pile of sedimentary rocks of late carboniferous to early to middle Triassic age hosts huge repository of Permian coal in a linear fashion trending the NW-SE in these tracts (Raja Rao 1983) and regionally 15 (seam no. I-XV) coal seams were delineated within the Barakar formation with varying thickness.

\section{Methodology and sampling}

For petrological studies, samples were selected from borehole sections. Depending on the compactness

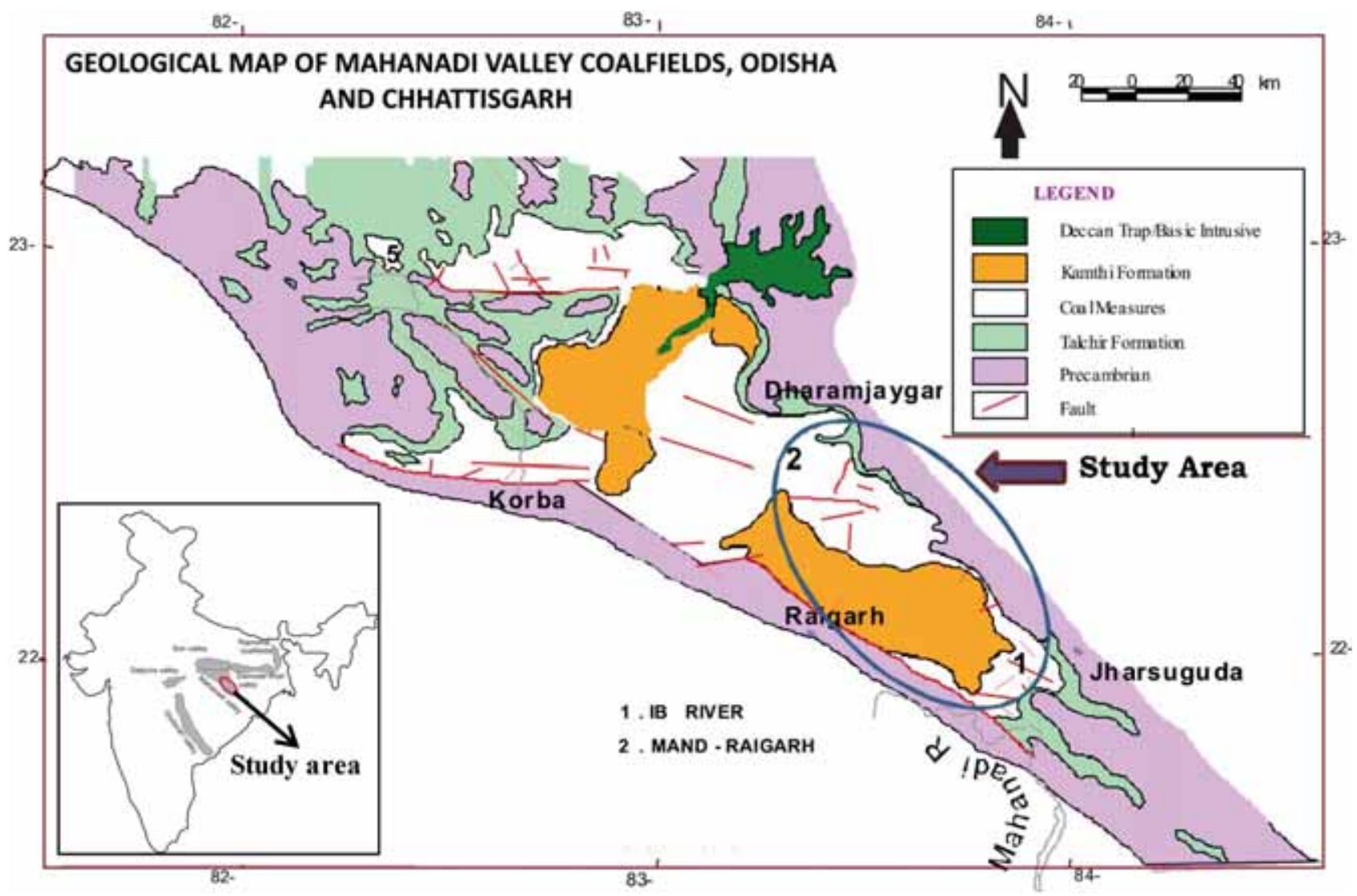

Figure 1. Geological map of the study area (modified after Raja Rao 1983). 
of the sample, blocks or pellets were processed. The surface across the bedding plane is polished for block samples and for pellets, the representative coal samples were ground and polished following Indian Standards and International Standards ISO 7404/2-1985(E). A petrographic study of the polished samples was carried out under reflected light fluorescence microscope (model Leica DMRXP) with photometer PMT III attached with software MSP-200 and image work station with LAS (Leica Application Suite) software, following ISO 7404-3; 1994 (E) and 7404-5: 1994 (E). For the identification of different macerals, International Committee for Coal and Organic Petrology - ICCP system 1994 (ICCP 1998, 2001; Pickel et al. 2017) nomenclature was followed.

\section{Results and discussion}

\subsection{Rank of coal}

Rank or maturity of coal seams was determined by measuring vitrinite reflectance $\left(\mathrm{Ro}_{\text {mean }} \%\right)$ (table 1$)$. In the $\mathrm{Ib}$ river coalfield, the samples studied show vitrinite reflectance $\left(\mathrm{VRo}_{\text {ran }} \%\right)$ varying from $0.30 \%$ to $0.53 \%$ with increasing depth from 53.40 to $706.50 \mathrm{~m}$. Whereas the Mand-Raigarh coalfield shows vitrinite reflectance $\left(\mathrm{VRo}_{\text {ran }} \%\right)$ ranging from $0.35 \%$ to $0.57 \%$. Rank-wise coal can be categorised under sub-bituminous to high-volatile bituminous C type (ASTM 1963) in both the coalfields. The similarities in the vitrinite reflectance value within the coal suggest the seams are formed from the same kind of source material and similar diagenesis levels within the coalification process. The gradual increase of the rank with respect to the depth of deposition also suggests that the coal seams were formed within uninterrupted vitrinitisation following a normal coalification path without any external heat influence. Based on vitrinite reflectance measurements, the samples with VRo\% less than $0.45 \%$ lie within the zone of early stage of oil generation, whereas the reflectance values of $0.5-0.57 \%$ indicate the beginning of commercial oil generation from coal within the diagenesis stage (Hunt 1996).

\subsection{Macerals and mineral matters}

Detailed petrographic data comprising maceral and mineral matter percentages as well as microlithotype percentage of all the samples are given in tables 1 and 2. The maceral and microlithotype are used as palaeo-environmental indicators for the interpretation of coal facies and depositional environment.

\subsubsection{Macerals}

Ib river coalfield: In Raniganj formation, R-III and R-I zones were studied which exhibit high percentage in the vitrinite $(38.53-53.92 \%)$ group of macerals with a consistently higher liptinite content $(12.92-27.45 \%)$. An inertinite group of macerals is present in moderate to high levels with varying content of mineral matters (figure 2). Moreover, the vitrinite reflectance value (VRomean \%) ranging from $0.31 \%$ to $0.40 \%$ categorise the coal under the sub-bituminous type (table 1).

In the Barakar formation, samples were collected from Belpahar, Parkhani, Lajkura and Rampur (from top to bottom) seam zones. The detailed maceral studies of the samples show moderate to high vitrinite content $(12.48-67.60 \%)$ as well as moderate to high liptinite content (12.43-35.92\%) except for a few samples, with less content. The inertinite group of macerals occurs in a low to moderate level (5.63-38.57\%) (figure 2). Mineral matter occurs in a low to moderate concentration except for a few samples. The vitrinite reflectance value (VRomean \%) ranges from $0.30 \%$ to $0.53 \%$ categorising the coal under sub-bituminous to high volatile bituminous $\mathrm{C}$ type (table 1 ).

Mand-Raigarh coalfield: The samples were collected from regional coal seam Nos. IX, VII, VI, IV, III, II and I (from top to bottom) of Barakar formation. Detailed maceral studies of the samples show a moderate to high vitrinite content (11.14-72.39\%) as well as a low to moderate percentage of liptinite (2.68-11.73\%) except for a few samples, which show higher value $(12.46-25.92 \%)$. The inertinite group is observed in a moderate to high (5.87$55.95 \%$ ) concentration (figure 2). Mineral matter is mainly present in a low to moderate level except for a few samples with higher values. The vitrinite reflectance value (VRomean \%) ranges from $0.35 \%$ to $0.57 \%$ categorising the coal under subbituminous to high volatile bituminous $\mathrm{C}$ type (table 1).

Vitrinite group of macerals: Detailed maceral studies reveal that most of the coal samples are rich in vitrinite content (figure 2) and the overall content varies from $11.15 \%$ to $72.39 \%$ (table 1 ). Total vitrinite present in the coal acts as reactive maceral taking part in the process of coal liquefaction along with liptinite. The high degree 


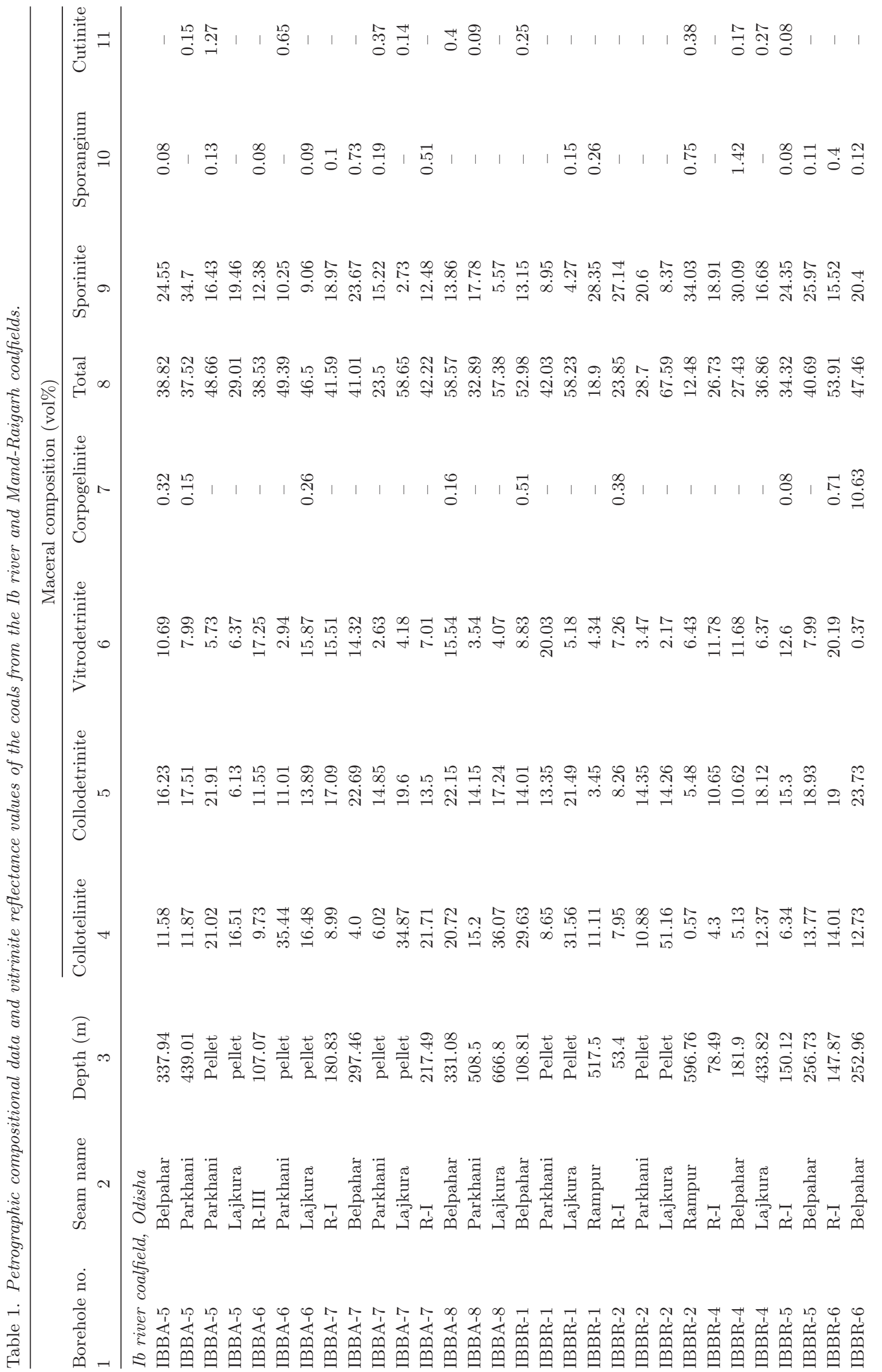




$$
\text { 궁 } 1+1, \frac{9}{8} \text { 영 }
$$

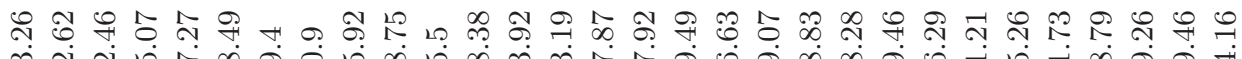

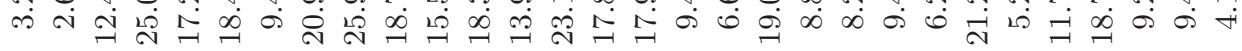

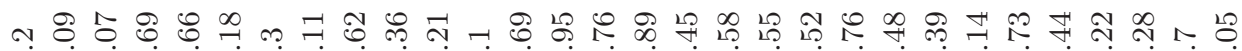
กิ่

ద

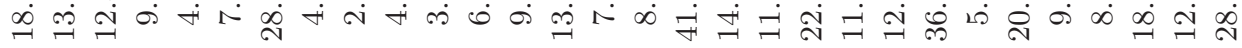

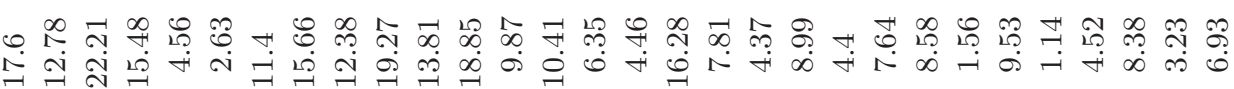

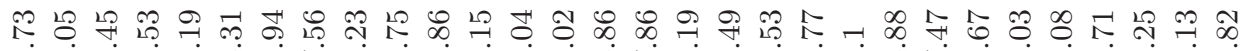
ம்

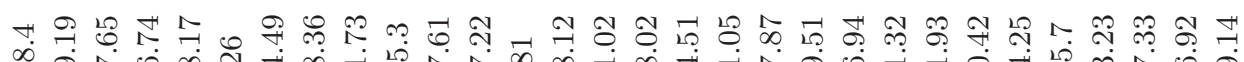

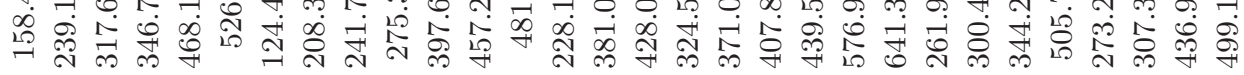

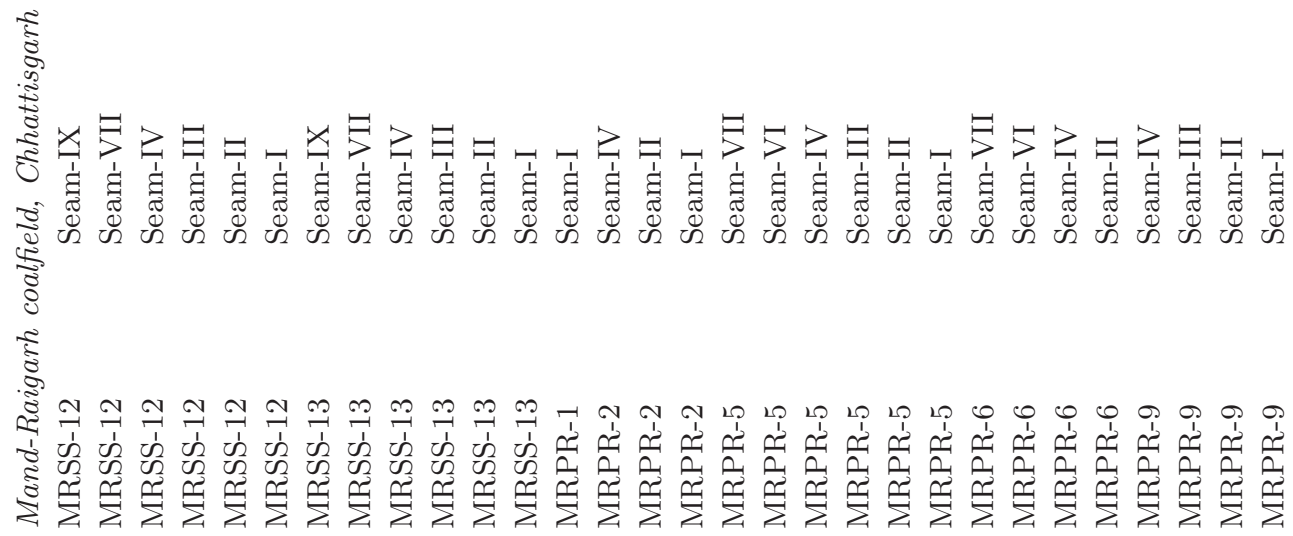




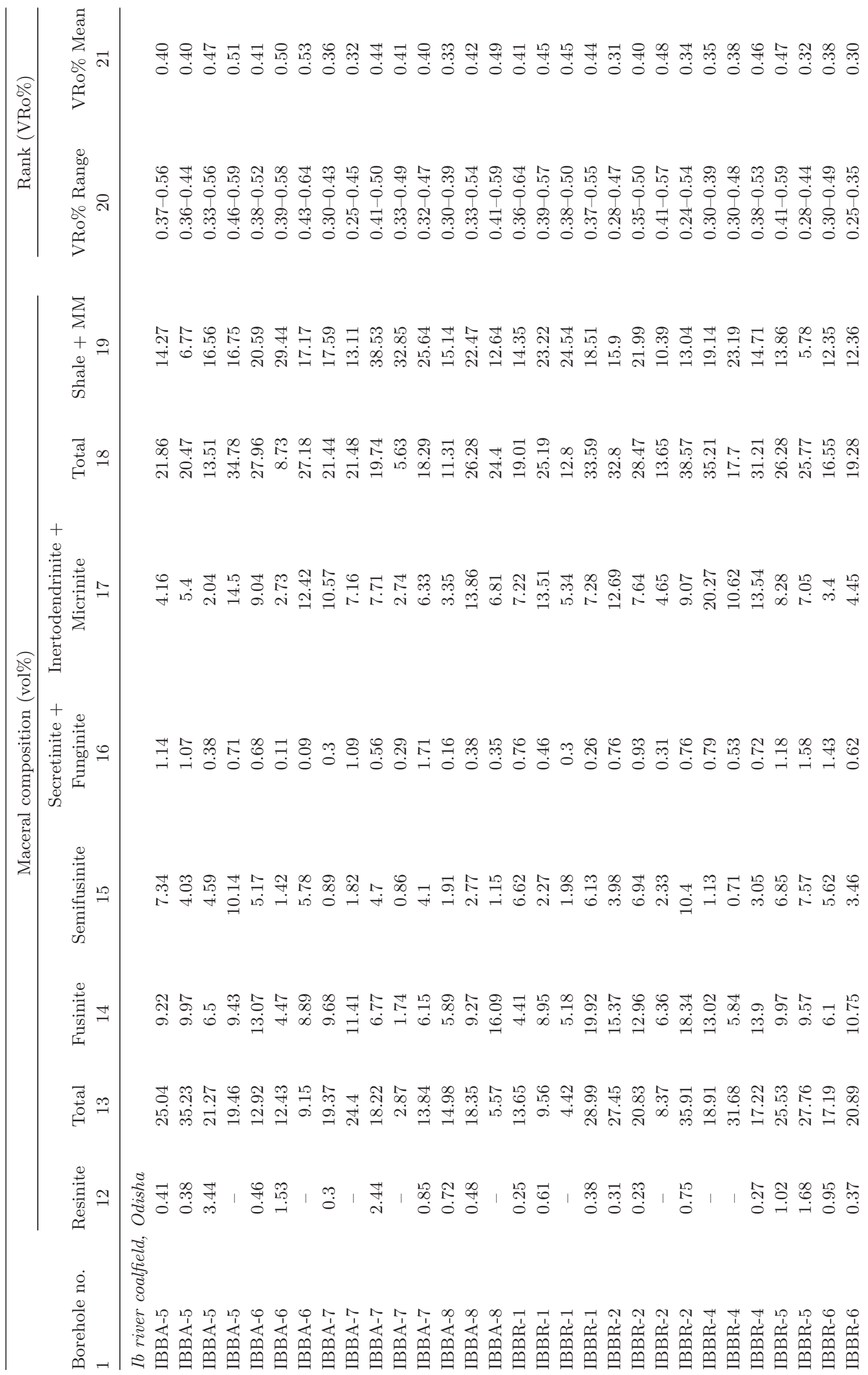




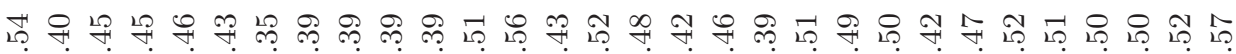

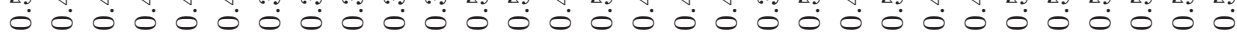

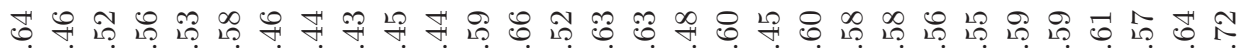

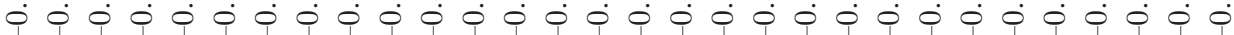

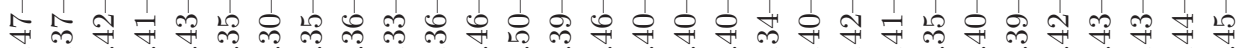

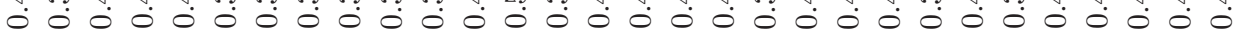

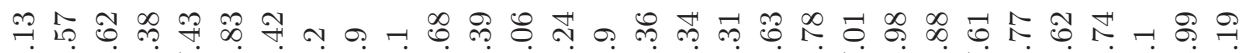

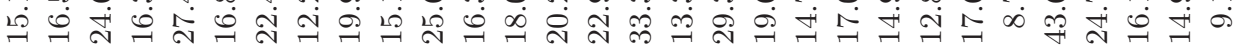

F ○

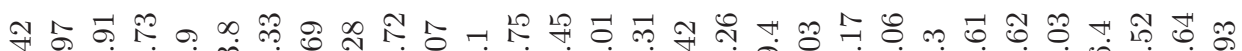
मी

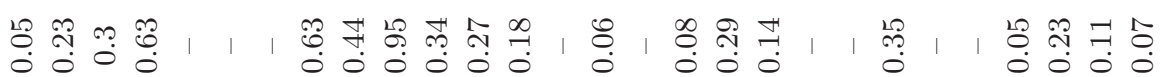

○ ద $-\dot{r}$ is

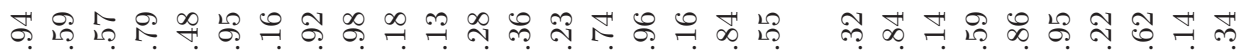

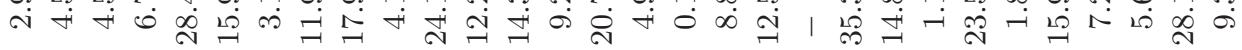

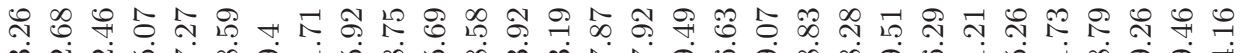

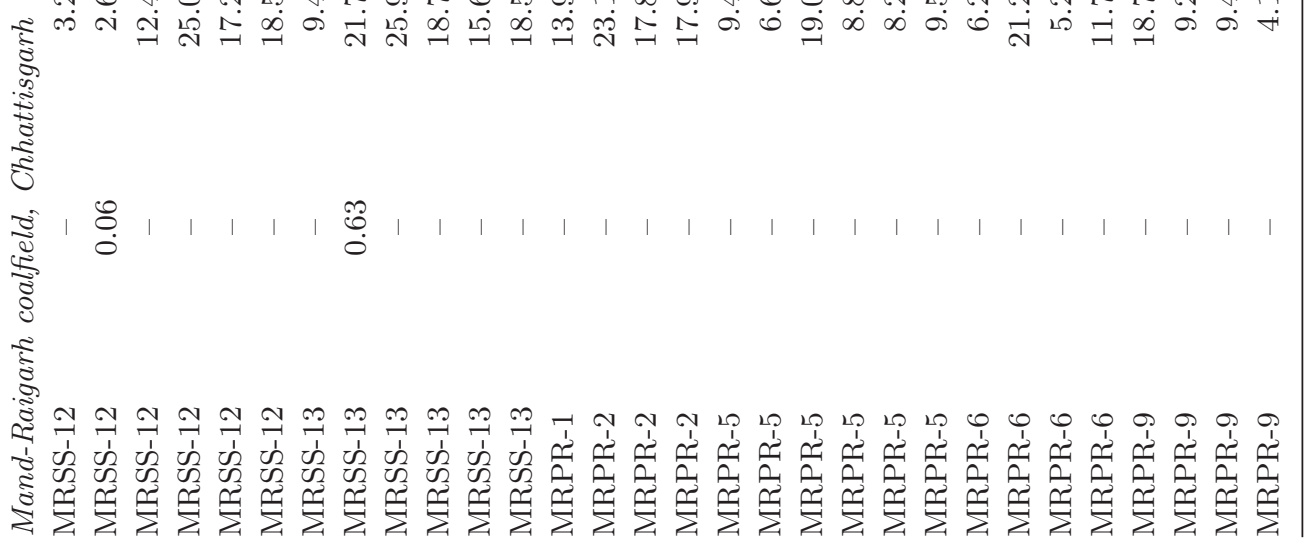




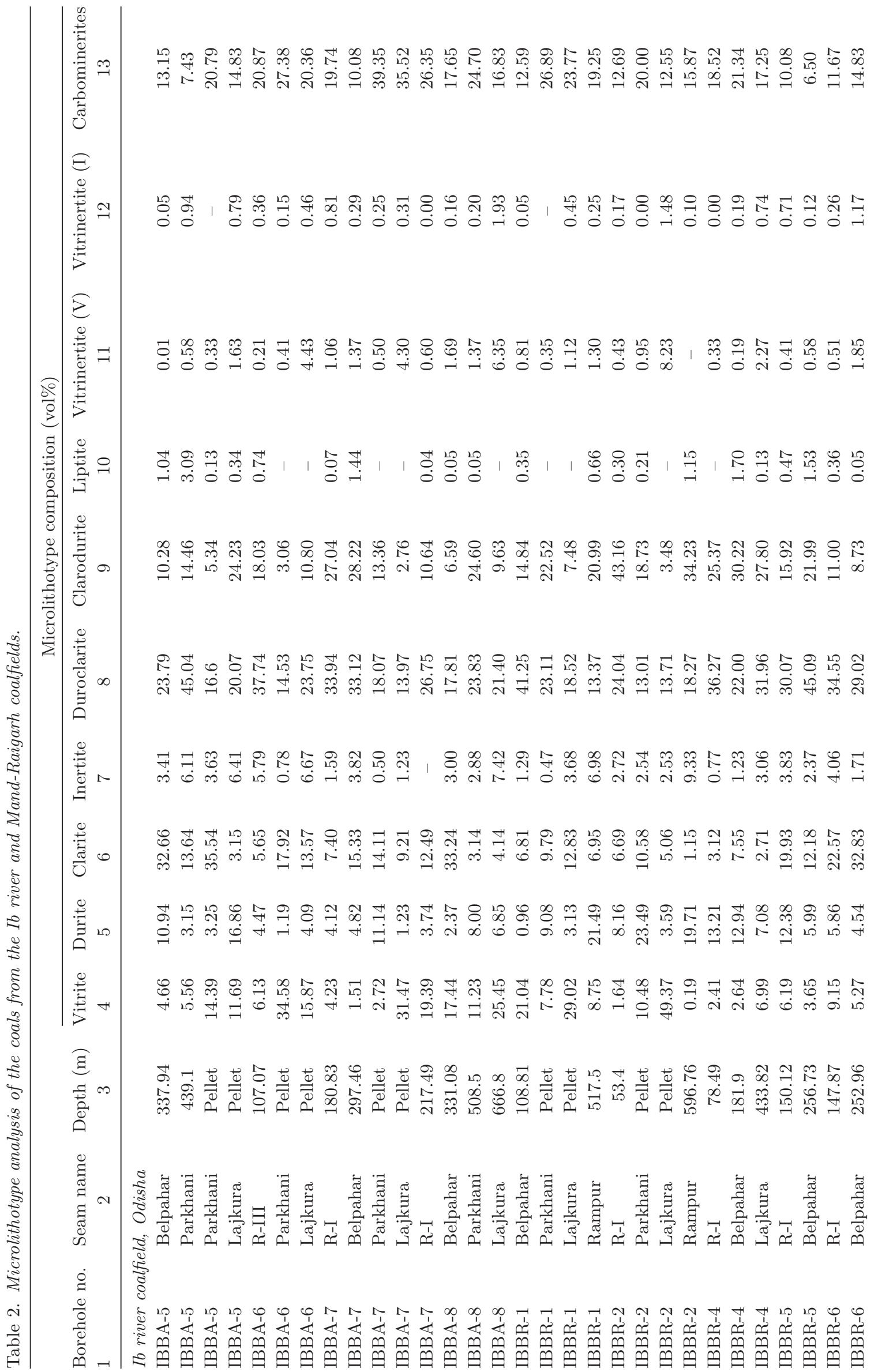




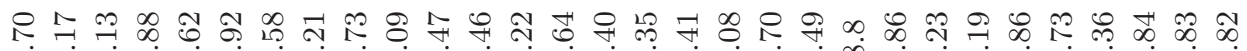
석 ล

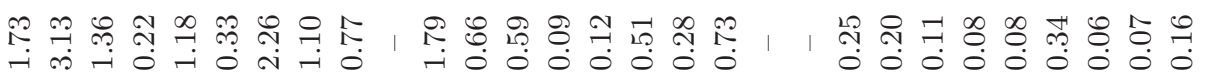

赵

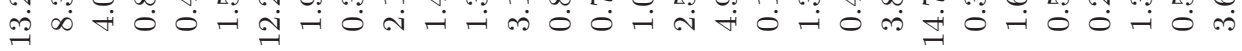

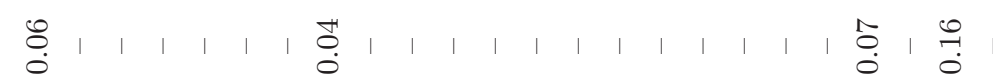

L -i山

$\exists$ ำ

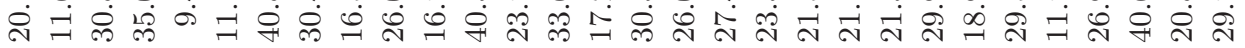

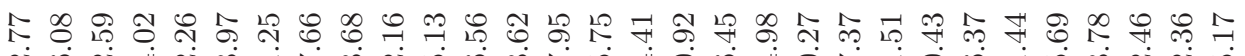
ง

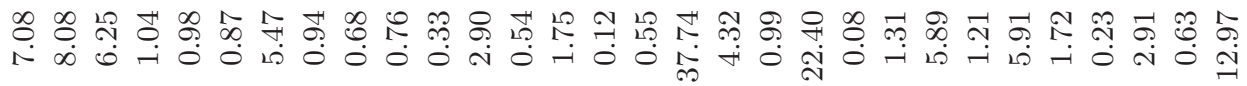

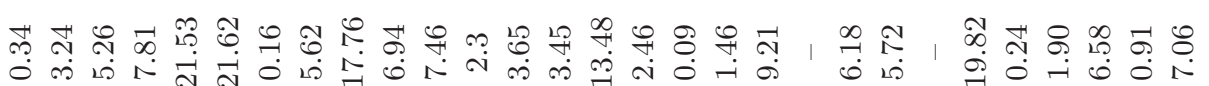

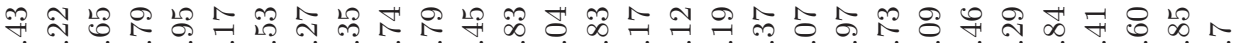
ฝீ

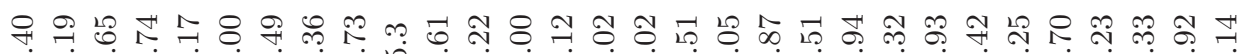

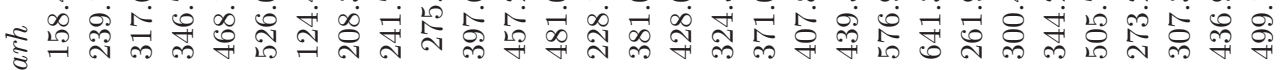
के

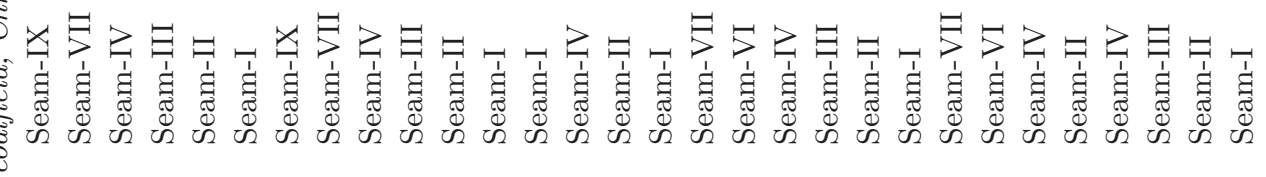
है 疍 d

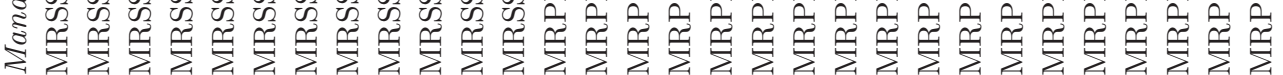




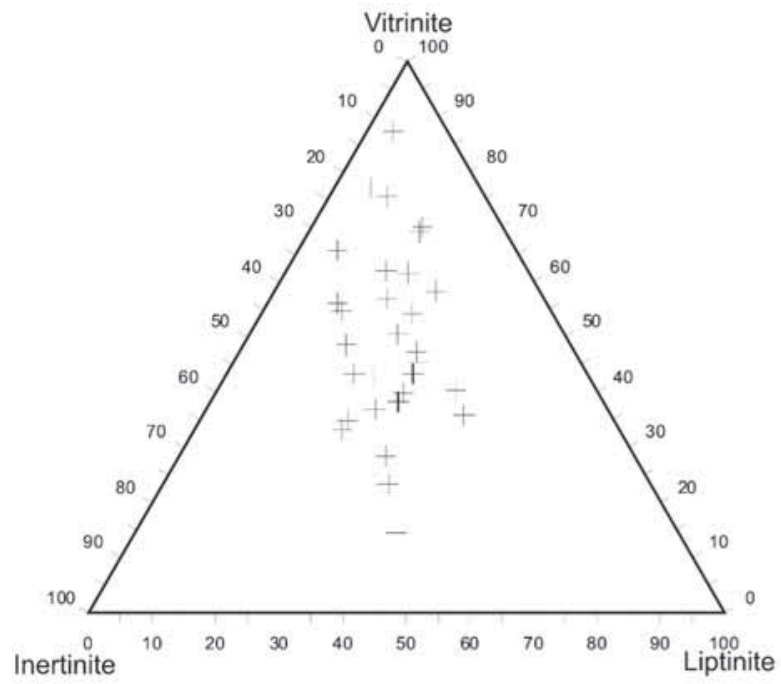

Ib River Coalfield

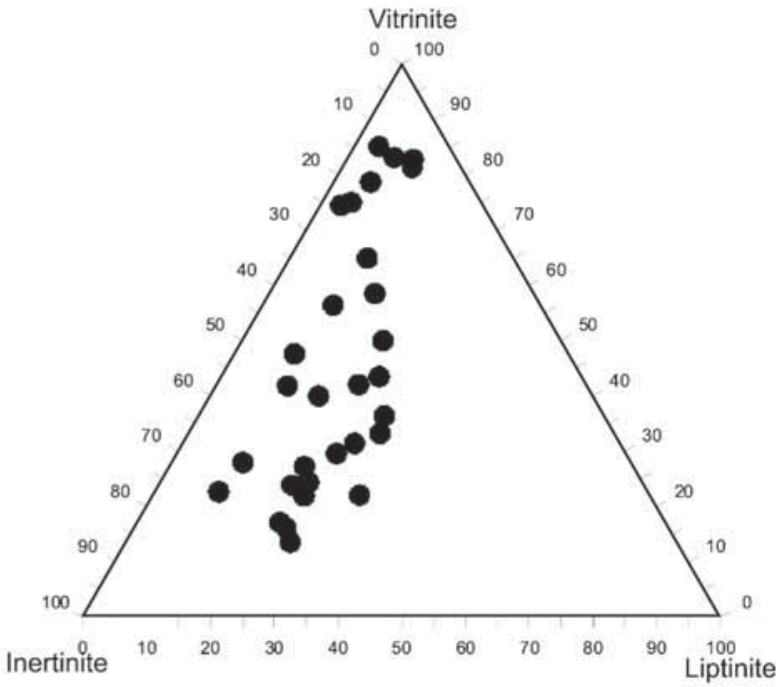

Mand-Raigarh Coalfield

Figure 2. Ternary diagram showing the maceral composition of coal samples from the Ib river and Mand-Raigarh coalfields.

of preservation of decayed plant material during vitrinisation resulted in the formation of homogenised vitrinite layers within the studied samples. The collotelinite (figures $3 \mathrm{c}$ and $5 \mathrm{~b}$ ) occurs as thick bands and varies from $0.57 \%$ to $51.16 \%$. Collodetrinite (figures $3 \mathrm{a}$, e and $4 \mathrm{c}$ ) varies from $1.14 \%$ to $23.73 \%$ and the total content of vitrodetrinite (figure 4e) present in the coal samples varies from $2.01 \%$ to $41.98 \%$. Corpogelinite $(0.08-10.83 \%)$ is present as discrete or an in situ excretion of vitrinite macerals as oval bodies to isolated grains or in the form of clusters (figure $3 \mathrm{e}$ ).

Liptinite group of macerals: Liptinite group of macerals are given importance not only due to their specific origin, peculiar characteristics in morphologies and also because of their high aliphatic nature as well as high in $\mathrm{H} / \mathrm{C}$ ratios compared to the other maceral groups (Stach et al. 1982). The total liptinite content in the studied samples varies from $2.68 \%$ to $35.92 \%$. Moderate to high content of liptinite in most of the samples is considered as an important factor in determining the reactive maceral content of the studied coal samples. In the sporinite subgroup, microsporinites (figures 3b, 4a and $5 \mathrm{f}$ ) are the major constituents followed by a few megasporinites (figure $5 \mathrm{c}$ ) with the overall content of sporinites varying from $2.62 \%$ to $34.70 \%$. Sporinites (micro and megasporinites) show wide range of shapes and reflectance features. The occurrence of sporangium is very rare; however, thick sporangium bodies $(0.05-1.42 \%)$ are observed in a few samples (figures $4 \mathrm{~b}$ and $5 \mathrm{~d}$ ). Cutinites are identified in the coal samples from its distinguished fluorescence colour, morphology and shape (figures $3 \mathrm{f}$ and $5 \mathrm{f})$. Cutinites are varying from $0.06 \%$ to $1.27 \%$. Resinites are observed in the coal samples occupied within the cell cavity of fusinites (figure 4d) or occur as isolated small spherical or oval bodies (figure 4a) and elongated thick bands (figures $3 \mathrm{~b}$ and $5 \mathrm{e}$ ). The percentage of resinite present in the coal samples varies from $0.06 \%$ to $3.44 \%$.

Inertinite group of macerals: The inertinite group of macerals exhibits a higher degree of aromatisation and condensation with higher carbon and lower oxygen and hydrogen content compared to vitrinite (Van Krevelen 1961). The maceral content in the samples ranges from $5.62 \%$ to $55.95 \%$. The macerals belonging to the inertinite group are fusinite, semifusinite, inertodetrinite and vitrodetrinite. Fusinite is identified by its high reflectance values and well-preserved cell structure or by bogen structure (figures 3a, c, $\mathrm{d}, 4 \mathrm{c}$ and $5 \mathrm{a}, \mathrm{b})$. Fusinite content ranges from $0.16 \%$ to $35.32 \%$, which occurs in thin layers in most of the samples. The cell cavities are filled up either by mineral matter (figure 5a) or by resinites (figure $4 \mathrm{~d}$ ). Due to plastic deformation, folding in the fusinite band (figure $3 \mathrm{~d}$ ) is also observed. Remnants of woody tissues are observed in a few samples (figures $3 \mathrm{a}$ and $4 \mathrm{c}$ ). Semifusinite is characterised by partially preserved 

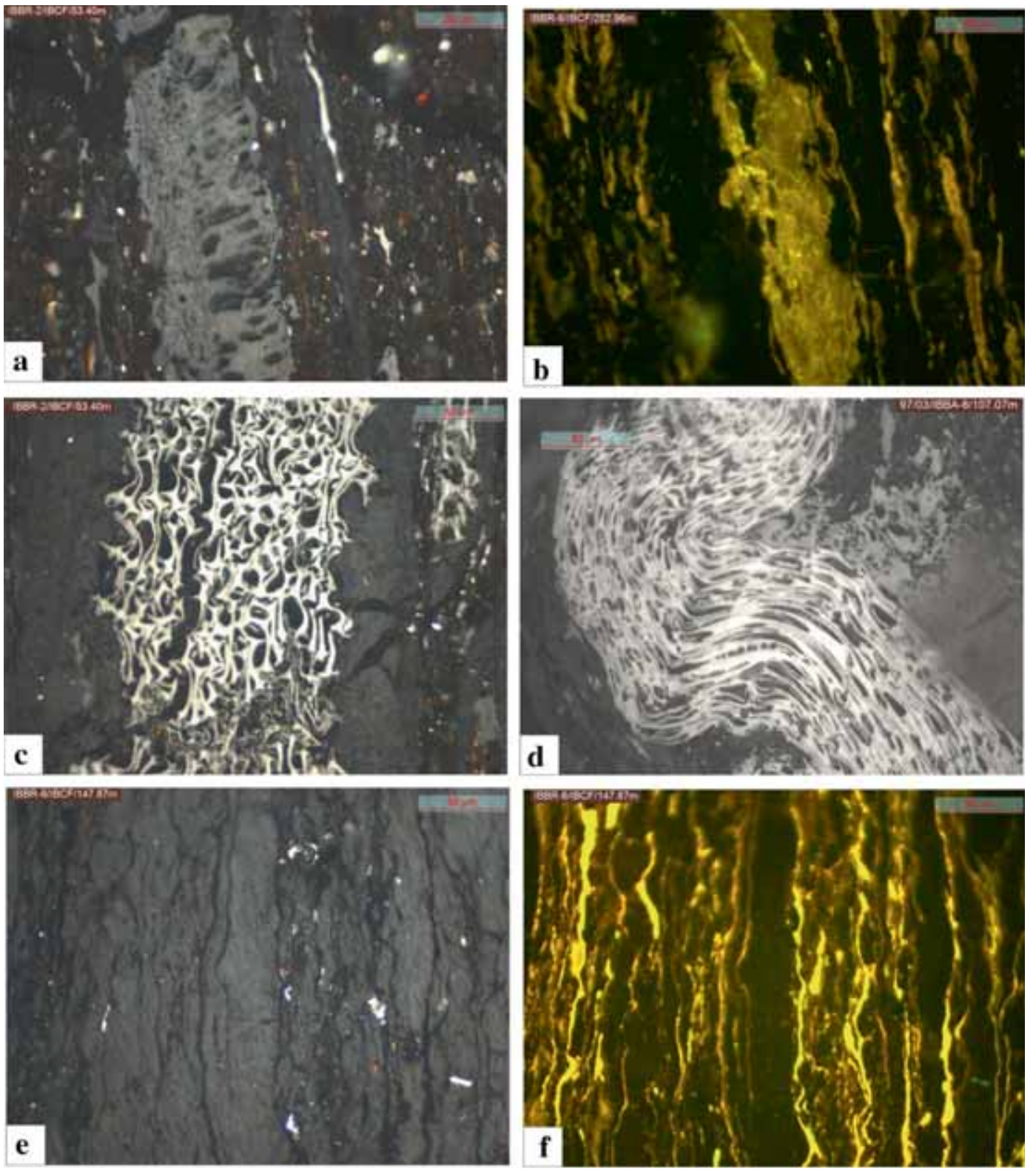

Figure 3. Photomicrographs of macerals and their association observed in coal polished section under oil immersion: (a) wood tissues (fusinite) within the clarodurite matrix; (b) resinite bands associated with microsporinites; (c) sharp contrast between fusinite (bogen structure) with collotelinite band; (d) microfolding in the fusinite band, cell walls are stretched on a folded band; and (e and f) densely packed leaf cuticles associated with collodetrinite bands (bottom left: section under normal incident light, right: same frame under the fluorescence mode of light).

cell structures (figure 5a) due to the incomplete fusinitisation having intermediate reflectance value between fusinite and telinite (ICCP 2001). Semifusinite in studied samples varies from $0.52 \%$ to $20.65 \%$. Inertodetrinites are fusinitised detrital plant fragments formed due to the redeposition of fragmented fusinite during the transportation or disintegration of fusinite under dry conditions of deposition of peat (figures $3 \mathrm{a}$, e and $4 \mathrm{e}$ ). Inertodetrinite varies from $2.04 \%$ to $29.40 \%$. Funginite and secretinites (0.05-1.58\%) occur in a small concentration (figure 4e).

\subsection{Mineral matters}

The inorganic constituents of coal occur in the form of mineral inclusions. In coal facies analysis, the mineral matter content indicates the periodic inundation of peat from a clastic marsh depositional environment. The minerals mainly observed 

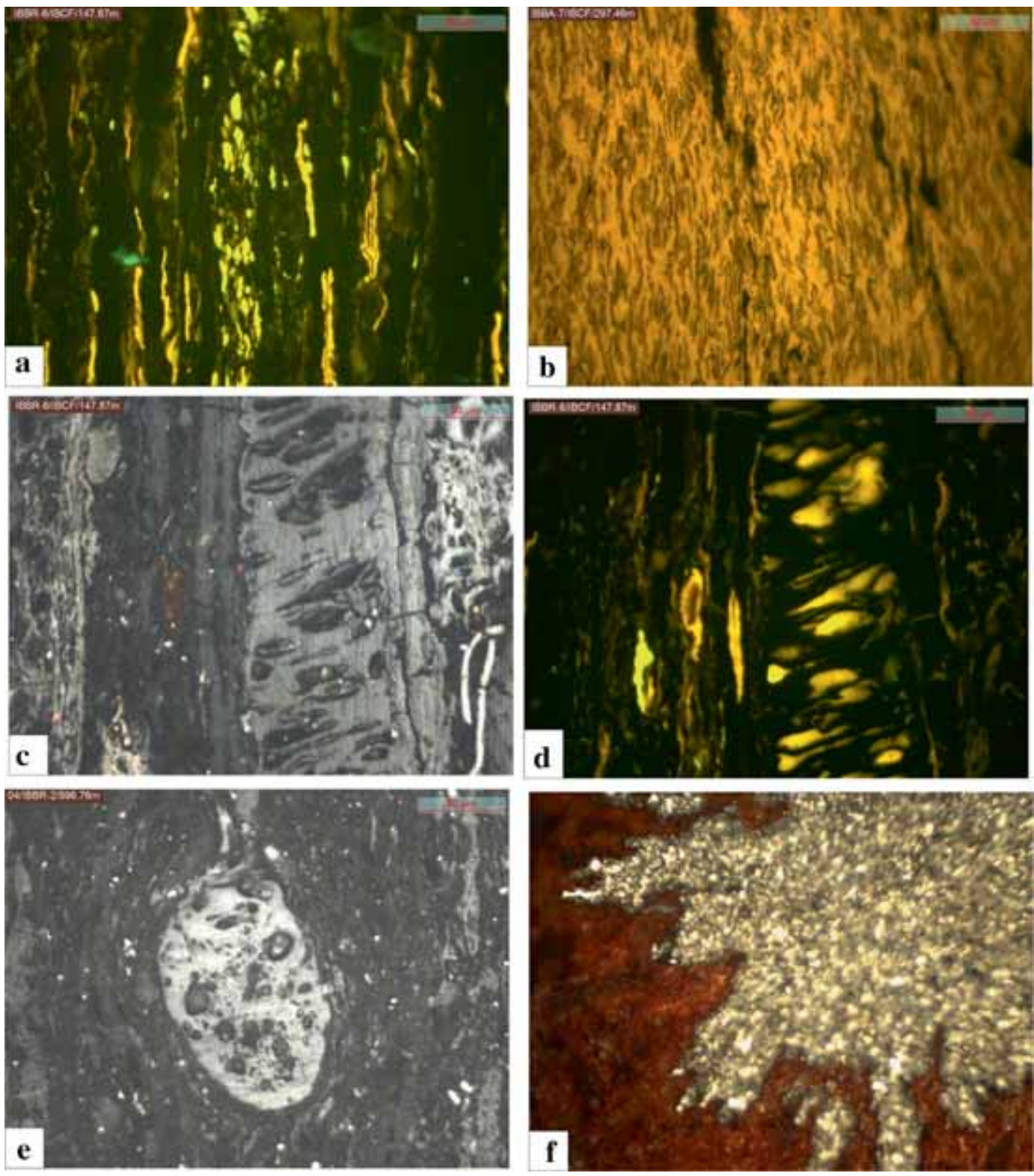

Figure 4. Photomicrographs of macerals, microlithotypes and mineral matters observed in the coal polished section under oil immersion: (a) funginite with resinous filling present within the clarodurite matrix, (b) thick sporangia body (liptite matrix), (c and $\mathbf{d}$ ) wood tissue within a clarodurite matrix (resinite filling within the cell lumens observed under the fluorescence mode), (e) large secretinite body and (f) siderite nodule associated with pyrite.

are silicates, clay minerals, pyrites and siderites. Most of the minerals present within the coal seams are mostly of epigenetic origin formed as a result of chemical precipitation (Diessel 1992) during or after the last stage of diagenesis and these occur within the cell lumens/cleats or fractures within the coal or as a replacement within the existing mineral (figures $4 \mathrm{f}$ and $5 \mathrm{a}$ ). The studied coal samples are characterised by a moderate amount of mineral matter, barring a few samples with high content. The total content of mineral matter in the coal samples varies from $5.78 \%$ to $43.62 \%$.

\subsection{Microlithotype analysis}

The coal samples from the Ib river coalfield reveal maximum association of trimacerites represented by duroclarite and clarodurite. The bimaceral group is dominated by the clarite group followed by the durite association. Monomacerals are mainly represented by vitrite and inertite. Liptite was also noted (figure 4b), associated with large sporangia bodies. Microlithotype analysis of coal samples from the Mand-Raigarh coalfield reveals an association of monomaceral dominant 

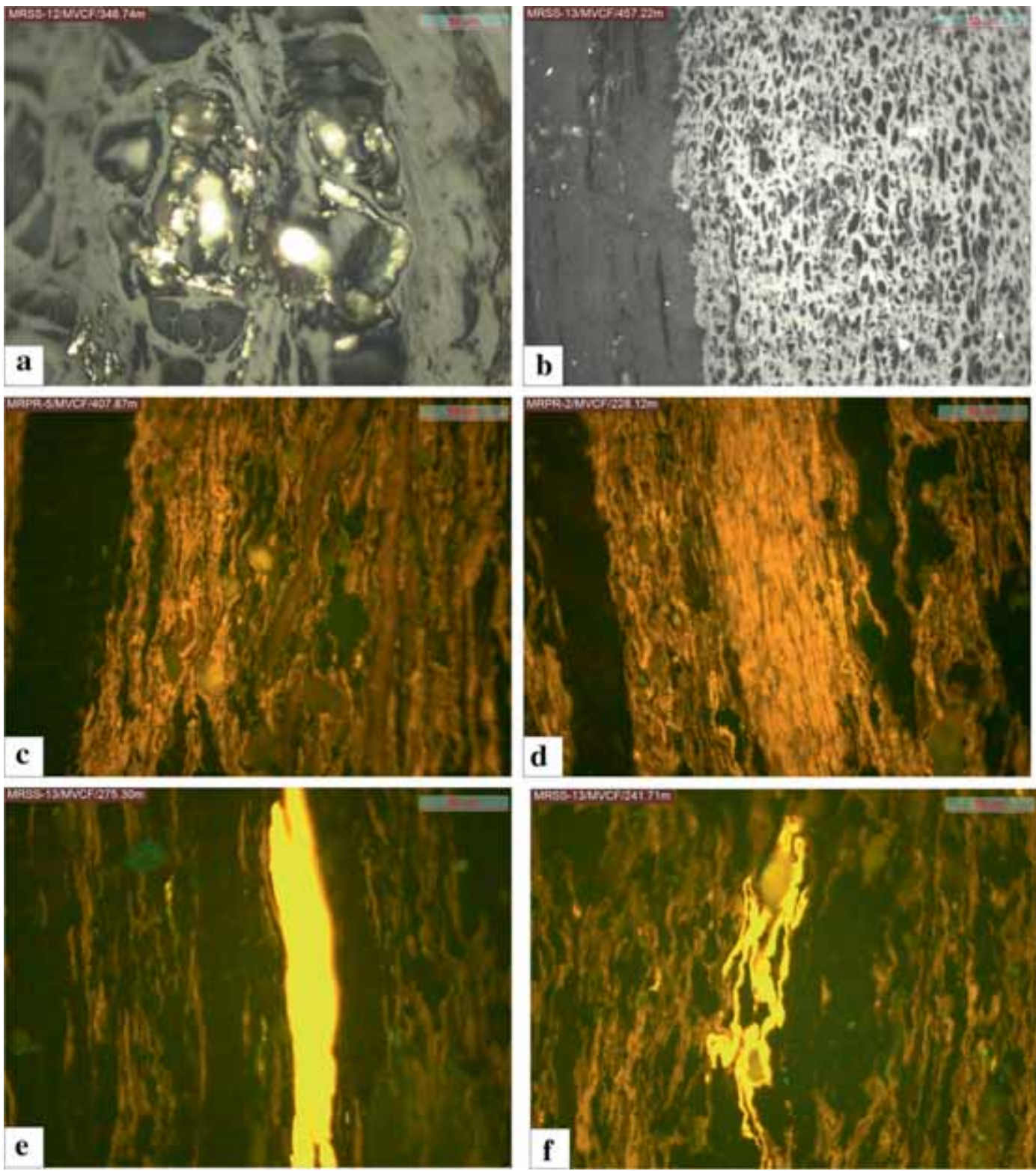

Figure 5. Photomicrographs of macerals and microlithotypes observed in coal polished section under oil immersion: (a) fusinite band with pyrite cell fillings; (b) bandings of fusinite (with a bogen structure) and collotelinite; (c) megaspore and microspore within the clarodurite matrix; (d) thick sporangia body associated with the microspore; (e) resinite bands associated with the microspore and (f) cutinites and microsporinites within the clarodurite matrix.

characterised by vitrite and inertite. Trimacerites are represented by duroclarite and clarodurite associations while bimaceral groups are represented by clarite and durite.

The carbominerites in all the studied samples were mainly represented by carbosilicates and carbargillite followed by carbopyrite (figures $4 \mathrm{f}$ and 5a) and carbankerite (figure 4f). The quantitative details of microlithotype occurrences of coal samples of the Ib river and Mand-Raigarh coalfields are given in table 2 .

\subsection{Coal facies analysis and depositional milieu}

Reconstruction of the depositional environment can be approached by coal facies analysis from the maceral ratios depicting the nature of vegetation and geochemical conditions prevalent during the peat formation. Different maceral ratios are used as palaeo-depositional indicators in interpreting the coal facies. Diessel $(1986,1992)$ developed two coal facies indices, namely, tissue preservation index (TPI) and gelification index (GI). GI contrasts geli- 
fied with fusinitised macerals while TPI emphasises on the degree of tissue preservation versus destruction. Furthermore, TPI is also used as an indicator of the degree of humification suffered by the precursor whereas GI relates to the measure of humidity in the coal swamp and indicates relative dryness or wetness of the coal-forming moor. The two indices are further modified by Lamberson et al. (1991), and defined as

$$
\mathrm{GI}=\frac{\text { Vitrinite }+ \text { Macrinite }}{\text { Inertinite }- \text { Macrinite }}
$$

vitrinite within the sample characterised by the deposition of coal seams in a limited clastic marsh settings under a slow subsidence condition, enhancing the microbacterial degradation of the peat. Coal samples that show high TPI and GI values suggest a telmatic condition of the mire under an anoxic environment of coal formation under a wet forest swamp condition and rapid burial of the peat. Coal samples that fall within low TPI and low GI values indicate the destruction of woody material due to extensive humification and mineralisation formed within a slowly sub-

$$
\mathrm{TPI}=\frac{\text { Telinite }+ \text { Collotelinite }+ \text { Semifusinite }+ \text { Fusinite }}{\text { Vitrodetrinite }+ \text { Corpogelinite }+ \text { Macrinite }+ \text { Inertodetrinite }} .
$$

The TPI represents the effect of the input of woody material and its final preservation whereas GI reflects the height of the water table during peat accumulation. From the projection of petrographic data of the $\mathrm{Ib}$ river and MandRaigarh coalfields (figure 6), most of the samples fall within high GI and low TPI coal facies. This suggests that the depositional environment of coal formation is in limnic to limno-telmatic settings and the wet condition of the mire with low tree density (Casareo et al. 1996). This is supported by the high percentage of unstructured siding relatively dry forest swamp settings. This is supported by the high percentage of inertinite macerals, mainly inertodetrinites and stable liptinite macerals.

The induction of various mineral matters and the percentage of these in the coal seams during the accumulation and preservation of peat influence the characteristics of coal to a great extent. A facies model has been used including mineral matter concentration along with other maceral composition (modified after Singh and Singh 1996) to understand the various conditions of peat

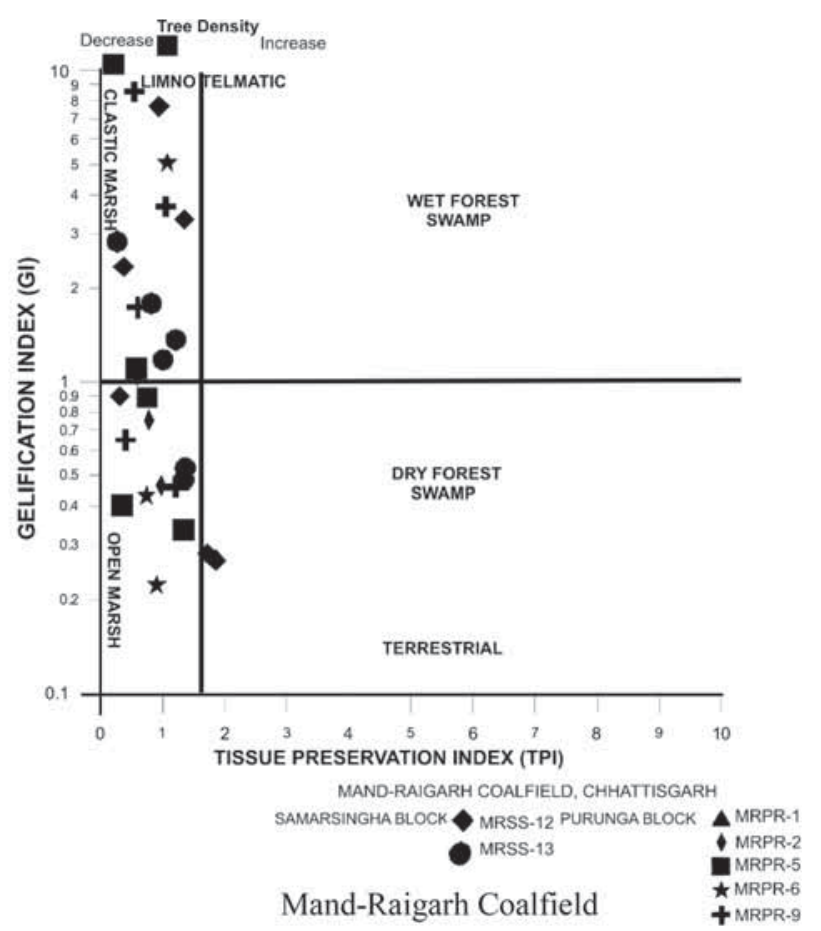

Figure 6. Diagram of TPI versus GI showing a palaeo-depositional environment of coal formation in the Ib river and MandRaigarh coalfields (modified after Diessel 1986). 


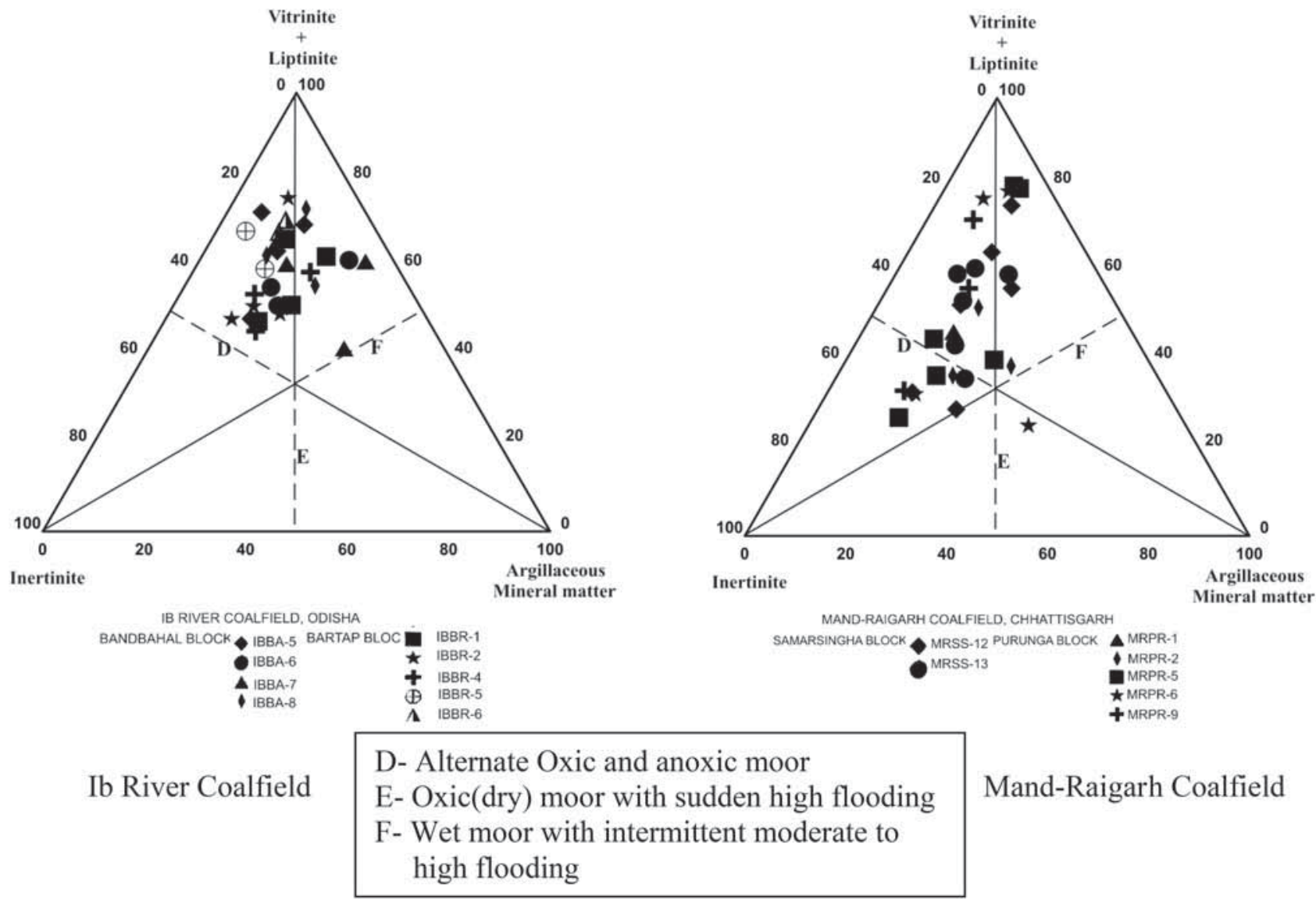

Figure 7. Depositional condition of coal formation in the Ib river and Mand-Raigarh coalfields (modified from Singh and Singh 1996).

formation in the Ib and Mand-Raigarh coalfields. In the $\mathrm{Ib}$ river coalfield, most of the coal seams evolved under an alternate oxic to anoxic moor to wet condition due to intermittent to high flooding in the palaeomire, while the coal seams of the Mand-Raigarh coalfield have been evolved under a fluctuating alternate oxic and anoxic condition to oxic conditions with a sudden high flooding of the mire (Naik et al. 2016) (figure 7).

The depositional milieu from microlithotype assemblages are studied for the interpretation of coal facies variation, which are recalculated on shale and mineral matter free basis. The lithotype assemblages represent different types of depositional environment from forest swamps to dry herbaceous/shrubby marshes. Compositional differences between lithotypes are due to vegetational characteristics as well as differences between the accumulation and deposition of peat communities. Lateral and vertical variations in lithotypes are controlled by ground water levels (sea-level changes and climatic conditions) and proximity to active fluvial systems (Diessel 1992) (figure 8).
The depositional milieu for peat formation in the Ib river and Mand-Raigarh coalfields of the Mahanadi valley coalfields are interpreted from microlithotype assemblages following Smyth (1984). The distribution plots of the two coalfields show a similar pattern of depositional milieu and indicate that the deposition was mainly under the lower and upper deltaic plain environmental setup, with a few scattered data embracing brackish depositional settings (figure 8). The deltaic environment of coal deposition indicates that these coals have fine to medium bandwidth and shows considerable degree of mixing by the maceral groups with a high concentration of trimacerite microlithotype. The lower delta plain is less affected by fluvial actions and sedimentation pattern but it is controlled by physical characteristics like water salinity, basin slope, energy regime, depth, sea level fluctuations and rate of subsidence with tectonic activities of the basins (Diessel 1992). These are the factors important for detrital matter influx to the seam during humification being close to the active centre of sedimentation and thus inhibit gelification. The 


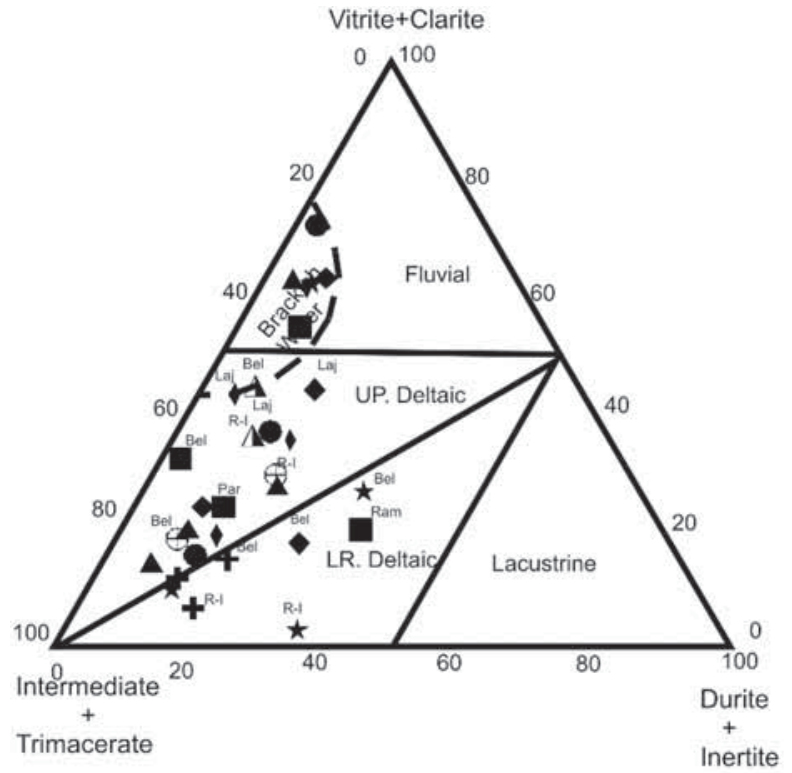

Bel:-Belpahar seam Par:-Parkhani seam Laj:-Lajkura seam
Rami-Rampur seam

BANDBAHAL BLOCK

IBBA-5
IBBA-6
ABBA-7
IBBA-8 BARTAP BLOCK Inertite

Ib River Coalfield

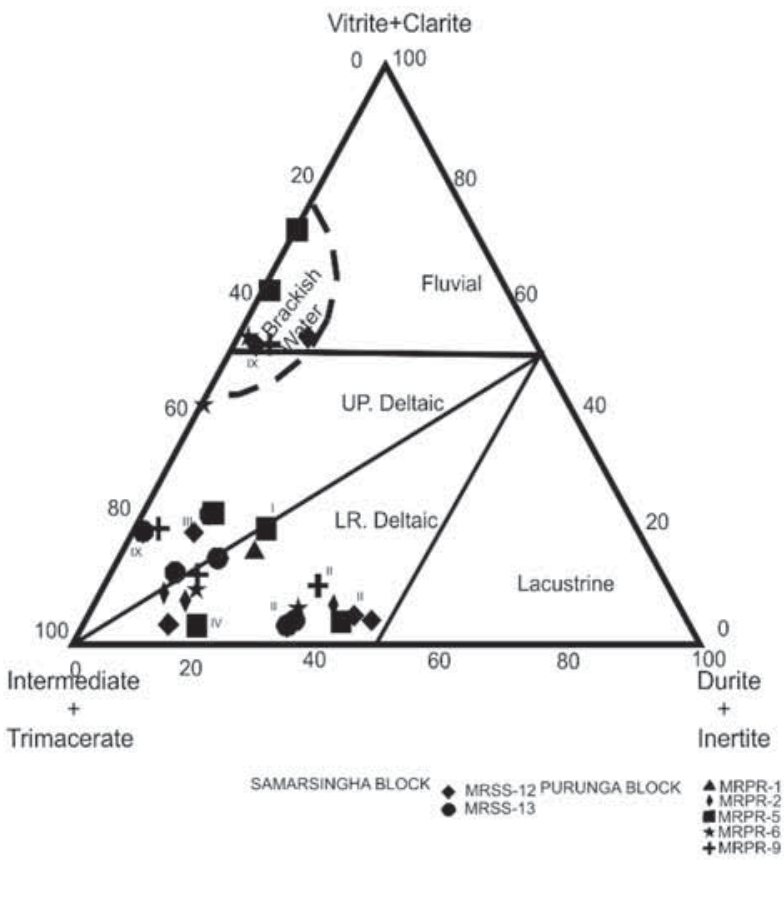

Mand-Raigarh Coalfield

Figure 8. Ternary diagram showing the depositional milieu of peat formation from microlithotypes for the Ib river and Mand-Raigarh coalfields (modified after Smyth 1984).

upper delta plain setting is more fluvial, dominated and characterised by a fresh ground water condition with no marine influence (Fielding 1985) and the biochemical coalification was thus influenced by elevated (neutral to just alkaline) $\mathrm{pH}$. Thus, an alkaline environment favoured the growth of bacteria, prompted decomposition and led to higher gelification (Teichmuller and Teichmuller 1982; Mc Cabe 1994).

\section{Conclusions}

A few coal seams from the $\mathrm{Ib}$ river and Mand-Raigarh coalfields are delineated by high vitrinite (up to $72.39 \%$ ), liptinite (up to $35.24 \%$ ) and reactive maceral content (up to $79.95 \%$ ). The rank studies reveal that the coal can be categorised under sub-bituminous to high volatile bituminous $\mathrm{C}$ type $(0.30-0.57 \%)$. The coal facies analysis indicates that the deposition of coal mostly under limnic to limno-telmatic conditions with low GI and high TPI, whereas some samples indicate low GI and low TPI values favouring the deposition of peat under open marsh settings results in the development of inertinite rich coal. However, a few coals show high GI and high TPI values, indicating telmatic settings under a wet forest swamp condition, resulting in the formation of vitrinite rich coal. The microlithotype composition of the coals suggests lower to upper deltaic conditions of the peat-forming milieu whereas some of the coal seams to indicate brackish water influx within the coal-forming swamp.

Coal as a potential source rock for oil generation is related to the depositional conditions of the coalforming precursors and variations in the coal facies which affects the hydrogen content in vitrinite-rich coal. R-I zones of Raniganj formation, Belpahar, Parkhani and Lajkura of Barakar formation from the Ib river coalfield and seam nos. VII, IV, III and I of the Barakar formation from the Mand-Raigarh coalfield are identified as suitable for coal liquefaction based on the results obtained from maceral, microlithotype studies and vitrinite reflectance values which correspond to immature to early mature stage of oil generation within the diagenesis stage.

\section{Acknowledgements}

The authors would like to express their gratitude to the director general, Geological Survey of India 
(GSI); DDG, NEnR, M-IIB, GSI, Kolkata for the overall guidance, cooperation, encouragement and permission to publish this work, and to the officers and colleagues of the Coal Petrography Division, NEnR, Mission-IIB for the motivation and valuable suggestions.

\section{References}

Brooks J D and Smith J M 1967 The diagenesis of plant lipids during the formation of coal, petroleum and natural gas; Geochim. Cosmochim. Acta 31 1183-1194.

Casareo F E, George S E, Battis B D and Conaghan P J 1996 The effect of varying tissue preservation on the aliphatic hydrocarbons within a high-volatile bituminous coal; Org. Geochem. 24 785-800.

Chaudhuri P N 1983 Geology and coal resources of Western Brajrajnagar area; Progress Report, Geol. Surv. Ind., F. S. 1978-1981, Ib River Coalfield, Sambalpur District, Odisha (unpublished).

Diessel C F K 1986 On the correlation between coal facies and depositional environment. Advances in the study of Sydney basin; In: Proceedings of the 20th Symposium, University of New Castle, Australia, pp. 19-22.

Diessel C F K 1992 Coal-bearing depositional systems; Springer, Berlin, 721p.

Durand B and Oudin J L 1979 Exemple de migrations des hydrocarbons; In: Proceedings of the 10th World Petroleum Congress I, Bukarest, Wiley, Chichester, pp. $1-9$.

Durand B and Parratte M 1983 Oil potentials of coal: a geochemical approach; In: Petroleum geochemistry and exploration of Europe (ed.) Brooks J, Blackwell Science Publication, Oxford, pp. 255-265.

Fielding C R 1985 Coal depositional models and distinction between alluvial and delta plain environments; Sed. Geol. 42 41-48.

Fleet A J and Scott A C 1994 Coal and coal bearing strata as oil-prone source rocks: an overview; Geol. Soc. Spec. Publ. 77 1-8.

Hunt J M 1996 Petroleum geochemistry and geology; 2nd edn, Freeman and Company, San Francisco, 617p.

International Committee for Coal and Organic Petrology (ICCP) 1998 The new vitrinite classification (ICCP system, 1994); Fuel 77 349-358.

International Committee for Coal and Organic Petrology (ICCP) 2001 The new inertinite classification (ICCP system, 1994); Fuel 80 459-471.

Lamberson M N, Bustin R M and Kalkreuth W D 1991 Lithotype (maceral) composition and variation as correlated with palaeo-wetland environments, gates formation, Northeastern British Columbia, Canada; Int. J. Coal Geol. 18 87-124.

Levine J R 1993 Coalification: The evolution of coal as a source rock and reservoir rock for oil and gas; In: Hydrocarbon from coal (eds) Law B E and Rice D D, AAPG 38 39-77.

Littke R, Leythaeuser D, Radke M and Schaefer R G 1990 Petroleum generation and migration in coal seams of the carboniferous Rhur basin, northwest Germany; Organic Geochem. 16 247-248.

Mc Cabe P J 1984 Depositional environment of coal and coal bearing strata; In: Sedimentology of coal and coal bearing sequences (ed.) Rahmani R M, Int. Assoc. Sedimentol. Spec. Publ. 7 13-42.

Naik A S, Singh M P, Volkmann N, Singh P K, Mohanty D and Kumar D 2016 Petrographic characteristics and Paleomires of Mand-Raigarh Coals, Mahanadi Gondwana Basin, Chhattisgarh, India; Int. J. Coal Sci. Technol. 3(2) 165-183.

Pickel W, Kus J, Flores D, Kalaitzidis S, Christanis K, Cardott B J, Misz-Kennan M, Rodrigues S, Hentschel A, Hamor-Vido M, Crosdale P and Wagner N 2017 Classification of liptinite-ICCP system 1994; Int. J. Coal Geol. 169 40-61.

Raja Rao C S 1983 Coal resources of Orissa, Coalfields of India; Bull. Geol. Surv. India 45(A2) 1-103.

Singh M P and Singh P K 1996 Petrographic characterization and evolution of the Permian coal deposits of the Rajmahal basin, Bihar, India; Int. J. Coal Geol. 29 93-118.

Singh P K 2012 Petrological and geochemical considerations to predict oil potential of Rajpardi and Vastan lignite deposits of Gujarat, Western India; J. Geol. Soc. India 80(6) 759-770.

Singh P K, Singh M P, Singh A K, Mukesh A and Naik A S 2013 Prediction of liquefaction behavior of East Kalimantan coals of Indonesia: An appraisal through petrography of selected coal samples; In: Energy sources part a: recovery, utilization, and environmental effects, vol. 35, Taylor \& Francis, London, UK, pp. 1728-1740.

Singh P K, Rajak P K, Singh V K, Singh M P, Naik A S and Raju S V 2016a Studies on thermal maturity and hydrocarbon potential of lignites of Bikaner-Nagaur basin, Rajasthan; In: Energy, exploration and exploitation, vol. 34, No. 1, SAGE Pub. Co. Ltd, UK, pp. 140-157.

Singh P K, Singh V K, Rajak P K, Singh M P, Naik A S, Raju S V and Mohanty D 2016b Eocene lignites from Cambay basin, Western India: An excellent source of Hydrocarbon; Geosci. Front. 7 811-819.

Singh P K, Singh V K, Singh M P and Rajak P K 2017a Petrographic characteristics and paleoenvironmental history of Eocene lignites of Cambay basin, Western India; Int. J. Coal. Sci. Technol. 4(3) 214-233.

Singh V P, Singh B D, Mathews R P, Singh A, Mendhe V A, Singh P K, Mishra S, Dutta S, Mahesh Shivanna M and Singh M P 2017b Investigation on the lignite deposits of Surkha mine (Saurashtra Basin, Gujarat), western India: Their depositional history and hydrocarbon generation potential; Int. J. Coal Geol. 183 78-99.

Smyth M 1984 Coal microlithotypes related to sedimentary environments in the Cooper Basin, Australia; Int. Assoc. Sedimentol. Spec. Publ. 7 333-347.

Stach E, Mackowsky MTh, Teichmuller M, Taylor G H, Chandra D and Teichmuller R (eds) 1982 Stach's textbook of coal petrology; Gebruder Borntraeger, Berlin, 535.

Teichmuller M and Teichmuller R 1982 Geol. Facies of coal formation; In: Stach's text book of coal petrology, Gebruder Borntraeger, Berlin, 537.

Teichmuller M and Durand B 1983 Fluorescence microscopical rank studies on liptinite and vitrinite in peat and coals 
and comparison with results of the Rock-Eval pyrolysis; Int. J. Coal Geol. 2 197-230.

Thomas B M 1982 Land plant source rocks for oil and their significance in Australian basins; APEA J. 22 164-178.
Tissott B P and Welte D H 1984 Petroleum formation and occurrence; 2nd edn, Springer, Berlin, 699.

Van Krevelen D W 1961 Coal typology-chemistry-physicsconstitution, Elsevier, New York, 35-126.

Corresponding editor: N V ChALAPATHI RAO 